\title{
Immunoregulatory $\mathbf{T}$ Cells in Man \\ Histamine-induced Suppressor T Cells are Derived from a Leu 2+ (T8+) Subpopulation Distinct from That Which Gives Rise to Cytotoxic T Cells
}

\author{
Paolo Sansoni, Earl D. Silverman, Manzoor M. Khan, Kenneth L. Melmon, and Edgar G. Engleman \\ Departments of Pathology, Medicine, and Pharmacology, Stanford University School of Medicine, Stanford, California 94305
}

\begin{abstract}
One mechanism of histamine-mediated inhibition of the immune response in man is to activate $T$ suppressor cells that bear the Leu 2 (OKT8) marker. The current study was undertaken to characterize the histamine-induced suppressor cell using a monoclonal antibody (9.3) shown previously to distinguish cytotoxic $\mathbf{T}$ cells from antigen-specific suppressor $\mathbf{T}$ cells. Leu $2+$ cells isolated from peripheral blood were further separated with antibody 9.3 into Leu $2+, 9.3+$, and Leu $2+, 9.3-$ subsets and each subset was incubated with different concentrations of histamine before determining their ability to suppress immune responses in vitro. The results indicate that the Leu $2+, 9.3-$ subpopulation includes all histamine-induced suppressor cells, that $10^{-4} \mathrm{M}$ histamine is the optimal concentration for suppressor cell induction, and that exposure of Leu 2+, 9.3- cells to histamine for $30 \mathrm{~s}$ is sufficient to initiate the induction process. After treatment with histamine these cells inhibit both phytohemagglutinin-induced $T$ cell proliferation and pokeweed mitogen-induced $B$ cell differentiation. The suppression of phytohemagglutinin-induced proliferation was resistant to $x$-irradiation with 1,200 rad, either before or after histamine exposure, suggesting that Leu $2+, 9.3$ - cells need not proliferate to become suppressor cells or exert suppression. Moreover, suppression by these cells was not due to altered kinetics of the response. Finally, a histamine type 2 receptor antagonist (cimetidine) but not a type 1 receptor antagonist (mepyramine) blocked the induction of suppressor cells. On the basis of these results and our previous studies of antigen specific suppressor cells, we conclude that Leu $2+$ suppressor cells in man are derived from a precursor pool that is phenotypically distinct from cells that can differentiate into cytotoxic $T$ cells.
\end{abstract}

\section{Introduction}

Histamine can inhibit a variety of lymphocyte functions, such as the proliferative response to mitogens and alloantigens (1, 2), antibody synthesis (3), cell-mediated lympholysis (4-7), and production of lymphokines (8). Although histamine may inhibit immunity by acting directly on lymphocytes, such as antibody-secreting B cells (3), studies from several laboratories

Address correspondence to Dr. Engleman, 800 Welch Rd., Palo Alto, CA 94304. Dr. Silverman is a Fellow of the Medical Research Council of Canada. Dr. Sansoni's present address is Istito Di Clinica, Medicale Generale, Parma University, Parma, Italy. 1984

Received for publication 2 July 1984 and in revised form 5 October

J. Clin. Invest.

(c) The American Society for Clinical Investigation, Inc.

0021-9738/85/02/0650/07 \$1.00

Volume 75, February 1985, 650-656 indicate that histamine can also regulate the immune response indirectly via the induction of suppressor $\mathrm{T}$ cells $(9-12)$. These histamine-induced suppressor cells have been shown to be included in the Leu-2+ (OKT8+) suppressor/cytotoxic subset (13-17) of $T$ cells $(11,12)$ and not in the Leu $3+($ OKT4+) helper/inducer subset $(14,16-18)$.

We have shown recently that the Leu $2+$ population can be divided with a murine monoclonal antibody, 9.3, into subpopulations that include precursors of antigen specific cytolytic (Leu 2+, 9.3+) and suppressor cells (Leu 2+, 9.3-) $(19-21)$. The aim of this study was to characterize these subpopulations of Leu $2+$ cells according to their ability to suppress the immune response after stimulation with histamine. The results indicate that the Leu $2+, 9.3-$ subpopulation includes all histamine-induced suppressor $T$ cells, and that after treatment with histamine, Leu $2+, 9.3-$ cells inhibit proliferative responses of autologous Leu 3+ cells to a variety of stimuli. Moreover, the induction of suppression seems to be mediated by $\mathrm{H}_{2}$ receptors on Leu $2+, 9.3-$ cells.

\section{Methods}

Drugs. Histamine dihydrochloride, cimetidine, and mepyramine maleate were purchased from Sigma Chemical Co., St. Louis, MO. Initial experiments (Fig. 1) indicated that $10^{-4} \mathrm{M}$ or $10^{-3} \mathrm{M}$ concentrations of histamine reproducibly induced $T$ suppressor cells under the conditions described below, and therefore, these concentrations were used in subsequent experiments.

Monoclonal antibodies. Anti-Leu 2a and anti-Leu 3a antibodies were provided by Dr. R. L. Evans, Memorial Sloan-Kettering Cancer Center, New York, and have been described previously (13-15). Antibody 9.3 was provided by Dr. J. A. Hansen, Fred Hutchinson Cancer Research Center, Seattle, WA. Initial studies of 9.3+ and 9.3$T$ cells have been described (19-22).

Isolation of E-rosetting and nonrosetting lymphoid cells. Peripheral blood mononuclear cells from healthy volunteers were obtained by Ficoll-Hypaque gradient centrifugation of fresh defibrinated blood (23). $\mathrm{T}$ cells and non- $\mathrm{T}$ cells were isolated by a single step rosetting method (24) using 2-aminoethylisothiouronium bromide hydrobromide (Sigma) treated sheep erythrocytes. Rosette-forming $(T)$ cells were separated on a second Ficoll-Hypaque gradient and freed from sheep erythrocytes by hypotonic lysis. The $\mathrm{T}$ cell fraction contained $>95 \%$ E-rosette forming cells. The non-T cell fraction included $40-50 \%$ surface Ig positive (B) cells, $30-50 \%$ alpha naphthyl acetate esterase positive phagocytic, plastic-adherent monocytes, and 5-10\% nonadherent nonphagocytic surface Ig negative, non-T, non-B cells.

Isolation of $T$ cell subpopulations. Purified subsets of $T$ cells were obtained by a "panning" technique that permitted the fractionation of fresh T cells into Leu 2+/Leu 2- or Leu 3+/Leu 3- subpopulations $(16,17)$. By using indirect immunofluorescence and cytofluorographic analysis of Leu 3 panned cells, $<2 \%$ of the unbound cells and $>95 \%$ of the bound cells were Leu $3+$. Similar purity of subsets was achieved when anti-Leu 2 was used as the panning antibody. The Leu 3population was further separated into $9.3+$ and $9.3-$ subsets by panning with the 9.3 antibody. Cytofluorographic analysis of the 9.3- 
subpopulation of Leu 3- cells showed that $<3 \%$ of the unbound cells were $9.3+$ compared with $>95 \%$ of the bound cells. Isolated subsets were suspended in RPMI 1640 medium supplemented with $25 \mathrm{mM}$ Hepes, $2 \mathrm{mM}$ L-glutamine, $100 \mu \mathrm{g} / \mathrm{ml}$ streptomycin, $100 \mathrm{U} / \mathrm{ml}$ penicillin, and $10 \%$ heat-inactivated pooled human serum, hereafter referred to as complete medium.

Cell cultures. Stimulation with phytohemagglutinin (PHA) ${ }^{1}$ (PHA-P, Burroughs Wellcome and Co., Beckingham, Kent, England) was carried out for $4 \mathrm{~d}$ at $37^{\circ} \mathrm{C}$ in an atmosphere of $5 \% \mathrm{CO}_{2}, 95 \%$ air. To determine the effects of histamine-treated lymphocytes on the response to PHA, $1 \times 10^{5}$ Leu $3+$ responder cells and $1.5 \times 10^{4}$ non$T$ accessory cells (irradiated to $1,500 \mathrm{rad}$ ) (cesium-137 unit, J. L. Shepherd and Associates, Glendale, CA) were co-cultured with different numbers $\left(1.25 \times 10^{4}\right.$ to $\left.1 \times 10^{5}\right)$ of histamine-activated cells (regulators) and $0.1 \mu \mathrm{g} / \mathrm{ml}$ PHA in a $0.2-\mathrm{ml} \mathrm{vol}$. Assays were performed in triplicate and $1 \mu \mathrm{Ci} /$ well of $\left[{ }^{3} \mathrm{H}\right]$ thymidine was added $18 \mathrm{~h}$ before harvesting with a MASH II apparatus (Microbiological Associates, Walkersville, MD). The incorporation of radiolabel in the cultures was measured by a liquid scintillation spectrometer (LS 7000; Beckman Instruments, Inc., Fullerton, CA) and the results are expressed as $\mathrm{cpm} \pm \mathrm{SEM}$.

A polyclonal plaque-forming assay (25) was used to detect Igsecreting B cells after their activation with pokeweed mitogen (PWM). Briefly, histamine-activated cells or control cells were co-cultured at a ratio of 1:1 with autologous Leu $3+$ cells and $1 \times 10^{5}$ autologous non-T cells in the presence of 1:100 PWM (Gibco Laboratories, Grand Island, NY). After $8 \mathrm{~d}$ of culture the cells were harvested and the number of plaque-forming cells (PFC) counted as described. The results are expressed as the mean \pm 1 SD of the number of PFC generated by $10^{6}$ non-T cells originally cultured. Percent suppression was calculated by the formula 1 - (PFC in the presence of regulators)/ (PFC in the presence of control cells) $\times 100$.

Induction of suppressor $T$ cells with histamine. Leu $2+$, Leu $2+$, 9.3-, or Leu $2+, 9.3+$ cells were cultured separately at a concentration of $1 \times 10^{6} \mathrm{cells} / \mathrm{ml}$ in complete medium alone (control cells) or with histamine $\left(10^{-3} \mathrm{M}\right.$ or $\left.10^{-4} \mathrm{M}\right)$ in the presence or absence of $2 \times 10^{-5}$ $M$ cimetidine $\left(\mathrm{H}_{2}\right.$ antagonist) or $10^{-6} \mathrm{M}$ mepyramine $\left(\mathrm{H}_{1}\right.$ antagonist) for $12 \mathrm{~h}$ at $37^{\circ} \mathrm{C}$. Leu $2+$ subsets were also cultured with cimetidine or mepyramine alone. After incubation the cells were extensively washed and resuspended in complete medium.

\section{Results}

Suppression of $P H A$ response by $T$ cell subsets preincubated with histamine. Preliminary studies confirmed that incubation of Leu $2+$ cells with histamine for $12 \mathrm{~h}$ activated cells that suppressed the response of Leu $3+$ cells to PHA (Fig. 1). Similar treatment of Leu $3+$ cells with histamine failed to induce suppressor cells (data not shown). To determine the optimal concentration of histamine for induction of suppressor cells, Leu $2+$ cells were cultured in the presence of varying concentrations of histamine for $12 \mathrm{~h}$ before assays of suppressor function. As shown in Fig. 1, generation of suppression was directly related to histamine concentration and maximal generation required a concentration of $10^{-3}$ or $10^{-4} \mathrm{M}$. Values in Fig. 1 reflect the proliferation of both Leu 3 responder cells as well as Leu 2 regulator cells to PHA. Net suppression is determined by comparing the proliferation with and without histamine pretreatment of Leu $2+$ cells at each regulator to responder ratio. In separate experiments both Leu 2 and Leu 3 cells were preincubated with varying concentrations of histamine $\left(10^{-2}-10^{-6} \mathrm{M}\right)$ and tested for their ability to respond

1. Abbreviations used in this paper: PFC, plaque-forming cell; PHA, phytohemagglutinin; PWM, pokeweed mitogen; Tdr, thymidine.

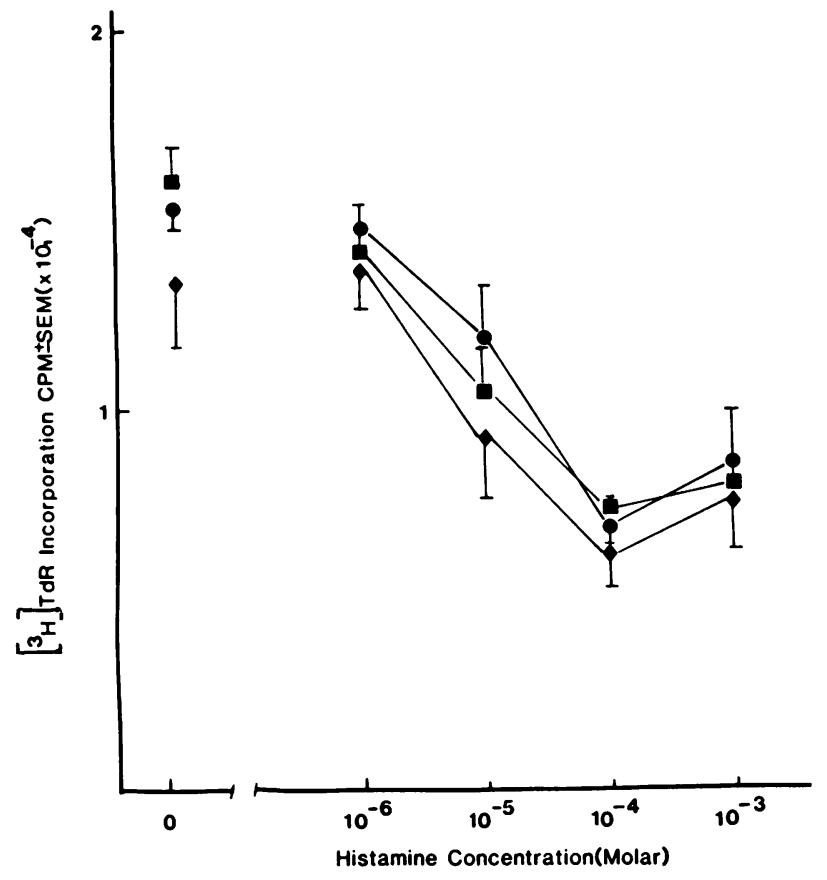

Figure 1. Effect of concentration of histamine on the generation of suppressor cells. Proliferative response to PHA of Leu 3+ cells in the presence of $1 \times 10^{5}(\bullet), 5 \times 10^{4}(\bullet)$, or $2.5 \times 10^{4}(\bullet)$ Leu $2+$ cells that had been exposed to varying concentrations of histamine. Tdr, thymidine.

to PHA. The responses of both subsets were unaltered by histamine pretreatment (data not shown).

To determine if subpopulations of Leu $2+$ cells differ in their ability to suppress the immune response after their exposure to histamine, Leu 2+, 9.3-, and Leu 2+, 9.3+ cells were incubated with or without $10^{-4} \mathrm{M}$ histamine at $37^{\circ} \mathrm{C}$ for $12 \mathrm{~h}$. Thereafter, the cells were washed extensively and cocultured in graded numbers with autologous Leu 3+ responder cells, accessory non-T cells (irradiated to 1,500 rad), and PHA. Fig. 2 shows that Leu 2+, 9.3- cells preactivated with histamine suppressed the response of Leu 3+ cells to PHA. The degree of suppression depended on the number of histamine-activated Leu $2+$ cells used and maximum suppression was detected at 1:1 and 2:1 ratios of responder to regulator cells. As in Fig. 1, values in Fig. 2 reflect proliferation of both responder and regulator cells to PHA. Net suppression is therefore determined in the same manner. In some experiments, untreated Leu 2+, $9.3+$ cells had a slight suppressive effect on proliferation. However, pretreatment of Leu $2+, 9.3+$ cells with histamine failed to induce any additional suppression, and on the contrary, often enhanced proliferation in indicator cultures.

Effect of $x$-irradiation on suppressor cell activation and function. In many systems, activation of suppressor cells is sensitive to doses of $x$-irradiation that prevent their proliferation. To determine if histamine-induced suppressor cells must proliferate in order to exert suppression, Leu $2+9.3-$ cells were irradiated with 1,200 rad before or after exposure to histamine and then tested for their ability to inhibit the response to PHA. Figs. $3 A$ and $B$ show that x-irradiation of Leu 2+, 9.3cells before or after their exposure to histamine had little or no effect on their ability to suppress the proliferative response of Leu 3+ cells to PHA. 


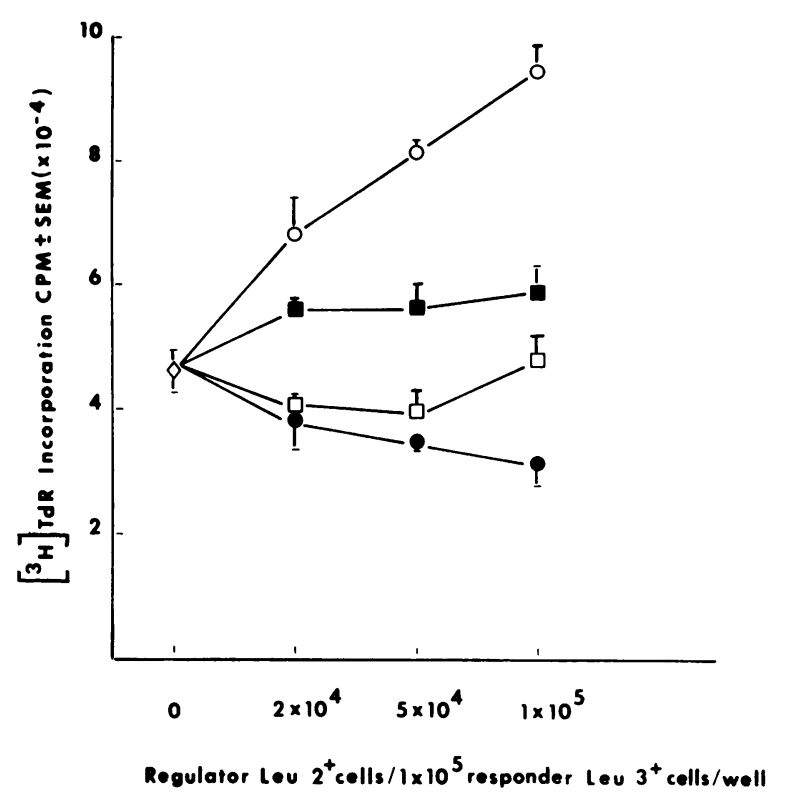

Figure 2. Proliferative response of Leu $3+$ cells to PHA in the absence $(\diamond)$ or presence of $10^{-4} \mathrm{M}$ histamine-activated Leu 2+, 9.3$(\bullet)$, or Leu $2+, 9.3+(\bullet)$ cells, or nonactivated Leu $2+, 9.3-(0)$, or Leu $2+, 9.3+(\square)$ cells.

Kinetics of suppressor cell activation. In all of the experiments described above, test cells were incubated in histaminecontaining medium for $12 \mathrm{~h}$ before their addition to fresh autologous lymphocytes and mitogen. Additional experiments confirmed that a minimum of $3 \mathrm{~h}$ was required for the generation of detectable suppressor cells and generation of maximal suppression required at least $6 \mathrm{~h}$ incubation (Fig. 4 $A$ ). On the other hand, the possibility existed that histamine was not required in the medium for the entire period. To explore this possibility, Leu $2+, 9.3-$ cells were incubated in histamine-containing medium for shorter periods, washed, and resuspended in fresh medium lacking histamine for the remainder of the 12-h incubation before suppressor cell assay. As shown in Fig. $4 B$, incubation of fresh Leu 2+, 9.3- cells in histamine for as little as $30 \mathrm{~s}$ (the shortest period tested) was sufficient to initiate the generation of suppressor cells.

Effects of $H_{1}$ and $H_{2}$ receptor antagonists on suppressor cell induction. In an attempt to determine the roles of $\mathrm{H}_{1}$ and $\mathrm{H}_{2}$ receptors in the histamine induction of Leu 2+, 9.3suppressor cells, Leu $2+$ subsets were cultured with $10^{-4} \mathrm{M}$ histamine in the presence of either $\mathrm{H}_{1}$ or $\mathrm{H}_{2}$ antagonists for $12 \mathrm{~h}$ at $37^{\circ} \mathrm{C}$, washed extensively, and then examined for their suppressor effect. As shown in Fig. 5, the presence of a saturating concentration of an $\mathrm{H}_{1}$ antagonist, mepyramine (26), did not affect the induction of suppressor cells with histamine. However, cimetidine, an $\mathrm{H}_{2}$ receptor antagonist, prevented the activation of suppressor cells by $10^{-4} \mathrm{M}$ histamine. Even when mepyramine and cymetidine were tested at equimolar concentrations $\left(2 \times 10^{-5} \mathrm{M}\right)$, only cymetidine prevented the induction of suppressor cells by histamine (data not shown). In experiments not shown, the same concentrations of mepyramine and cimetidine alone had no detectable effect on Leu 2+, 9.3-, or Leu-3+ proliferation.

Effect of histamine-activated suppressor $T$ cells on kinetics of the PHA response. As shown in Fig. 6, the suppressive effect
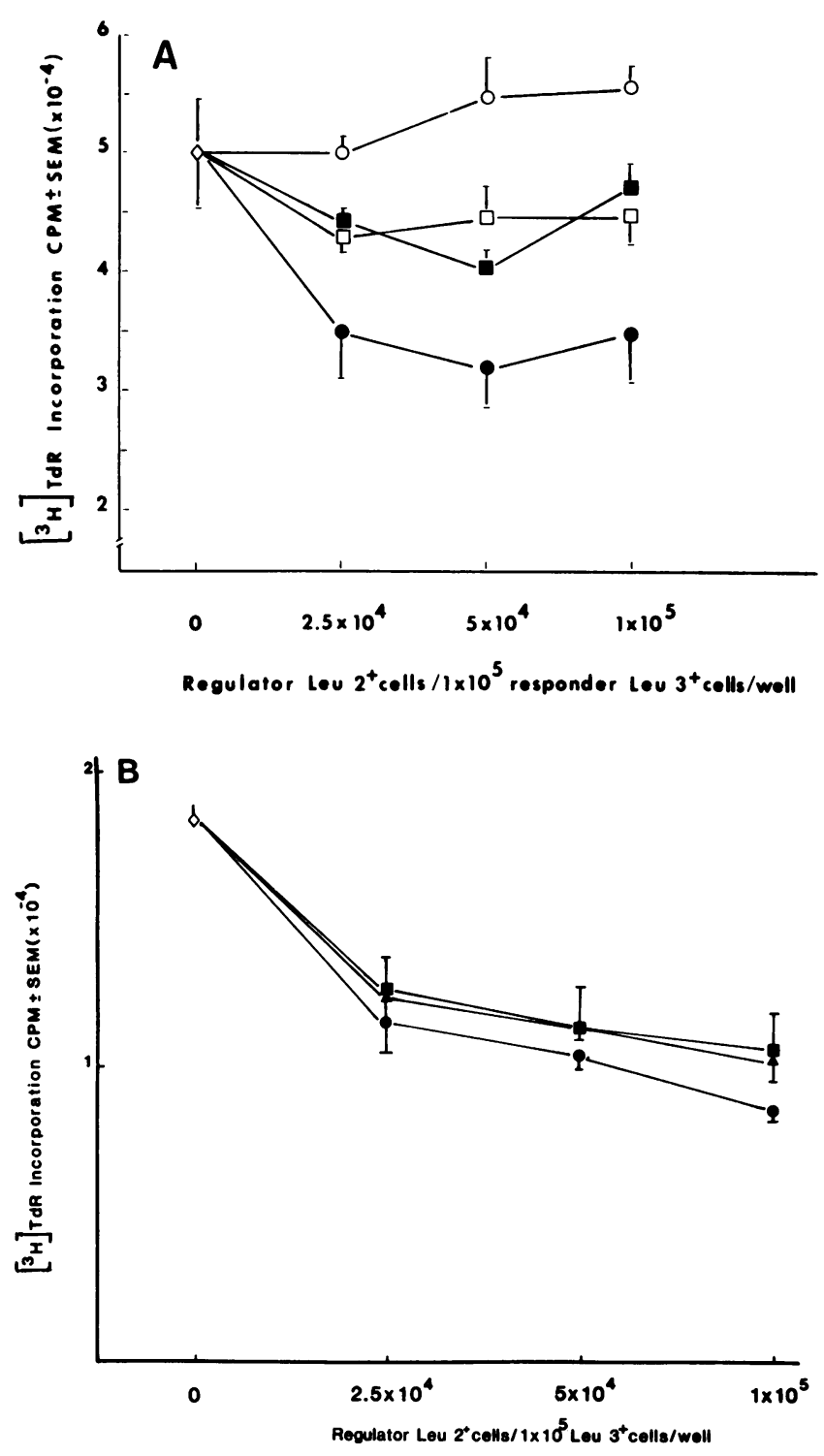

Figure 3. Effect of irradiation on suppressor cell generation and function. $(A)$ Proliferative response of Leu $3+$ cells to PHA in the absence $(\diamond)$ or presence of $10^{-4} \mathrm{M}$ histamine-activated and then irradiated $(1,200 \mathrm{rad})$ Leu $2+, 9.3-(\bullet)$ or Leu $2+, 9.3+(\bullet)$ cells, or nonactivated and irradiated Leu $2+, 9.3-(0)$, or Leu $2+, 9.3+(\square)$ cells. $(B)$ Proliferative response of Leu $3+$ cells to PHA in the absence $(\diamond)$ or presence of histamine-treated Leu $2+, 9.3-$ cells $(\bullet)$, Leu 2+, 9.3- cells irradiated $(1,200$ rad) before histamine treatment

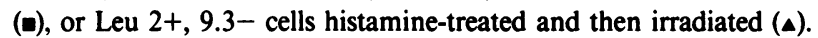

of histamine-activated Leu 2+, 9.3- cells was not due to a shift in kinetics of the proliferative response of Leu 3+ cells to PHA. Maximal suppression occurred at day 4 of culture, but significant inhibition was detected as early as $48 \mathrm{~h}$ after initiation of culture. As shown in the same figure, Leu 2+, $9.3+$ cells exposed to histamine had little or no effect on the Leu $3+$ cell response, regardless of the duration of culture.

Effect of histamine-induced suppressor cells on immunoglobulin synthesis. Leu 2+, 9.3+, and Leu 2+, 9.3- cells cultured with $10^{-3} \mathrm{M}$ or $10^{-4} \mathrm{M}$ histamine as described above, were mixed with autologous Leu $3+$ and autologous non-T cells and stimulated with PWM. Immunoglobulin-secreting 

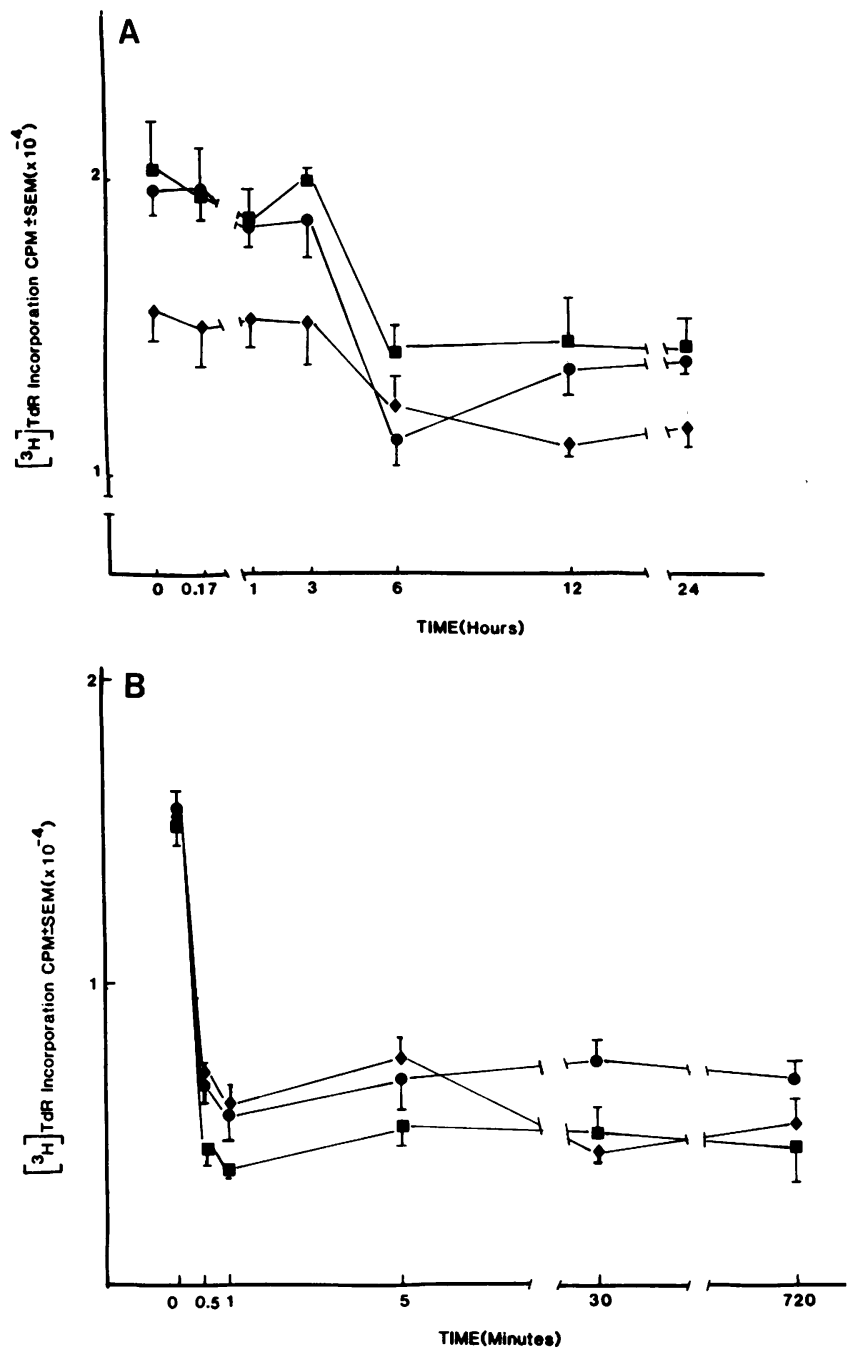

Figure 4. The effect of duration of histamine exposure on the generation of suppressor cells. $(A)$ Leu $2+, 9.3$ - cells were exposed to histamine for $0-24 \mathrm{~h}$, then tested at $1 \times 10^{5}(\bullet), 5 \times 10^{4}(\bullet)$, or 2.5 $\times 10^{4}(\bullet)$ cells/well for their ability to suppress the proliferative response of Leu 3+ cells to PHA. (B) Leu 2+, 9.3- were exposed to histamine for 0-12 h, washed, and resuspended in fresh medium for the remainder of a 12-h incubation. These cells, at $1 \times 10^{5}(\boldsymbol{m}), 5 \times$ $10^{4}(\bullet)$, or $2.5 \times 10^{4}(\bullet)$ cells/well, were then tested for their ability to suppress the proliferative response of Leu $3+$ cells to PHA.

cells in these cultures were measured after $8 \mathrm{~d}$ with a reverse hemolytic plaque assay. The results of two representative experiments are shown in Table $I$ and demonstrate that preincubation of Leu $2+, 9.3-$ cells with histamine enhanced the suppressive effect of these cells on the generation of PFC. Although there is variation in the degree of suppression between experiments, in both experiments the potency of suppression is related to the concentration of histamine present during the preincubation phase.

In another series of experiments $H_{1}$ and $H_{2}$ receptor antagonists were added with histamine to define the role of histamine type 1 and 2 receptors on suppressor cell activation. As shown in Table II, mepyramine did not significantly reduce the histamine-induced suppressive activity of Leu 2+, 9.3cells on immunoglobulin synthesis. However, cimetidine completely blocked the effect of $10^{-4} \mathrm{M}$ histamine and partially reversed the effect of $10^{-3} \mathrm{M}$ histamine. Leu $2+, 9.3+$ cells

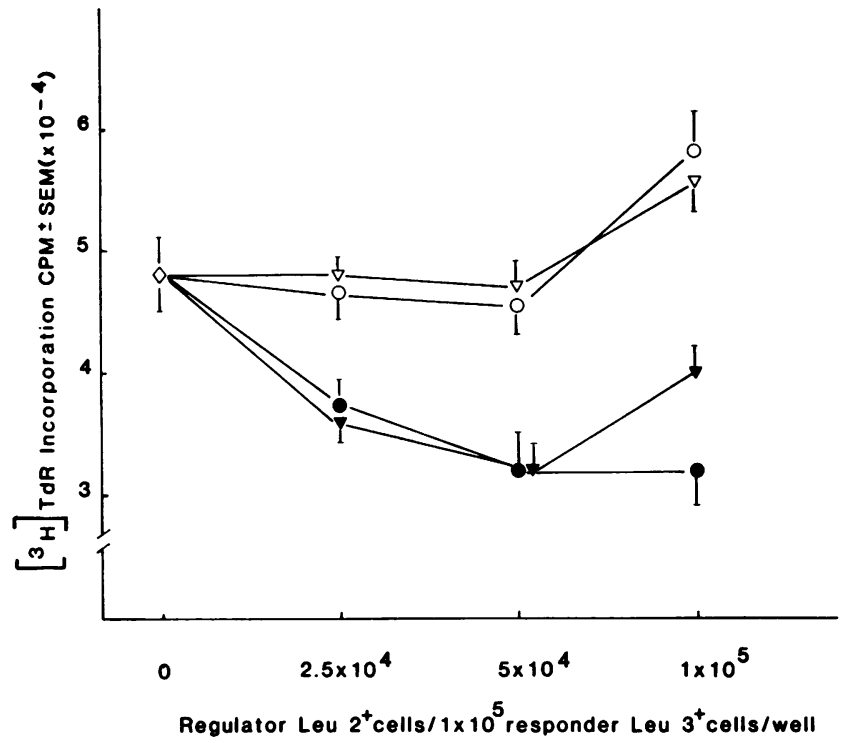

Figure 5. Effect of histamine antagonists on histamine-mediated induction of Leu 2+, 9.3- suppressor cells. PHA response of Leu 3+ cells alone $(\diamond)$ or in the presence of Leu $2+, 9.3-$ cells precultured in medium (o), $10^{-4} \mathrm{M}$ histamine (๑), histamine plus $10^{-6} \mathrm{M}$ mepyramine $\left(\mathrm{H}_{1}\right.$ antagonist $)(\nabla)$, or histamine plus $2 \times 10^{-5} \mathrm{M}$ cimetidine $\left(\mathrm{H}_{2}\right.$ antagonist) $(\nabla)$.

failed to inhibit PFC formation, and incubation of these cells with histamine in the presence or absence of $\mathrm{H}_{1}$ or $\mathrm{H}_{2}$ antagonists did not significantly modify the number of PFC. Incubation of Leu $2+, 9.3-$, or Leu $2+, 9.3+$ cells with either $\mathrm{H}_{1}$ or $\mathrm{H}_{2}$ antagonist alone at the concentrations used, did not significantly modify the number of PFC (data not shown).

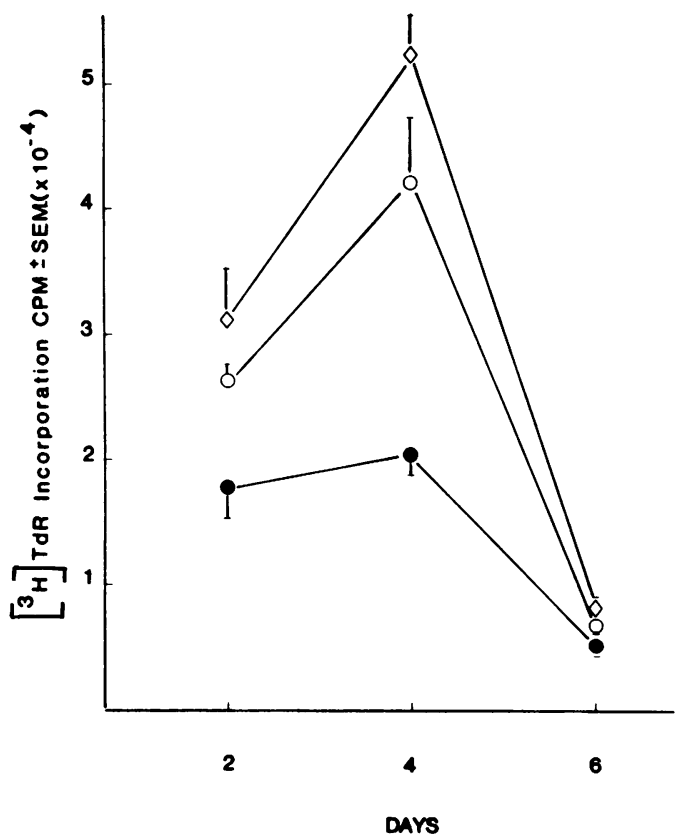

Figure 6. Kinetics of PHA response of Leu 3+ cells alone $(c)$ or in the presence of an equal number of Leu $2+, 9.3+$ precultured with $10^{-4}$ histamine (O), or Leu $2+, 9.3-$ cells precultured with $10^{-4} \mathrm{M}$ histamine (๑). 
Table I. Effect of Histamine-treated Leu 2+ Subsets on PWM-Induced Immunoglobulin Synthesis

\begin{tabular}{|c|c|c|c|c|c|c|}
\hline \multirow[b]{2}{*}{ Regulators* } & \multicolumn{3}{|l|}{ Experiment 1} & \multicolumn{3}{|l|}{ Experiment 2} \\
\hline & Treatment & PFC $\ddagger$ & Suppression & Treatment & PFC & Suppression \\
\hline & & & $\%$ & & & $\%$ \\
\hline \multicolumn{7}{|c|}{ Leu $2+, 9.3-$} \\
\hline & None & $102,633 \pm 14,500$ & & None & $81,000 \pm 2,666$ & \\
\hline & Histamine $\left(10^{-4} \mathrm{M}\right)$ & $62,216 \pm 10,333$ & 39 & Histamine $\left(10^{-4} \mathrm{M}\right)$ & $63,000 \pm 7,666$ & 22 \\
\hline & Histamine $\left(10^{-3} \mathrm{M}\right)$ & $26,833 \pm 2,950$ & 74 & Histamine $\left(10^{-3} \mathrm{M}\right)$ & $49,833 \pm 2,433$ & 38 \\
\hline \multicolumn{7}{|c|}{ Leu $2+, 9.3+$} \\
\hline & None & $100,166 \pm 7,166$ & & None & $91,333 \pm 11,166$ & \\
\hline & Histamine $\left(10^{-4} \mathrm{M}\right)$ & $86,000 \pm 7,333$ & 14 & Histamine $\left(10^{-4} \mathrm{M}\right)$ & $84,333 \pm 1,333$ & 8 \\
\hline & Histamine $\left(10^{-3} \mathrm{M}\right)$ & $100,160 \pm 9,823$ & 0 & Histamine $\left(10^{-3} \mathrm{M}\right)$ & $80,666 \pm 5,500$ & 12 \\
\hline
\end{tabular}

* Each culture contained PWM, $1 \times 10^{5}$ non-T cells, $2 \times 10^{5}$ Leu $3+$ cells, and $2 \times 10^{5}$ histamine-treated Leu $2+$ subpopulation as regulators. $\ddagger \mathrm{PFC} \pm 1$ SD per $10^{6}$ non-T responder cells initially cultured.

\section{Discussion}

This study provides evidence that histamine selectively triggers suppressive activity in a subpopulation of Leu $2+$ cells that lacks the 9.3 marker. The induction of suppression was dependent on both the concentration of histamine and the duration of culture of Leu 2+, 9.3- cells following their exposure to

Table II. Effect of $\mathrm{H}_{1}$ and $\mathrm{H}_{2}$ Antagonists on Histamine-induced Activation of Suppressor Cells of Immunoglobulin Synthesis

\begin{tabular}{|c|c|c|c|}
\hline Regulators* & Treatment & PFC $\ddagger$ & Suppression \\
\hline & & & $\%$ \\
\hline \multirow[t]{11}{*}{ Leu $2+, 9.3-$} & None & $81,000 \pm 4,706$ & \\
\hline & Histamine $10^{-4} \mathrm{M}$ & $63,000 \pm 7,102$ & 22 \\
\hline & Histaminine $10^{-4} \mathrm{M}$ & & \\
\hline & + mepyramine & $52,166 \pm 8,166$ & 36 \\
\hline & Histamine $10^{-4} \mathrm{M}$ & & \\
\hline & + cimetidine & $82,000 \pm 16,833$ & -1 \\
\hline & Histamine $10^{-3} \mathrm{M}$ & $49,833 \pm 2,633$ & 38 \\
\hline & Histamine $10^{-3} \mathrm{M}$ & & \\
\hline & + mepyrámine & $56,666 \pm 3,166$ & 30 \\
\hline & Histamine $10^{-3} \mathrm{M}$ & & \\
\hline & + cimetidine & $65,166 \pm 3,666$ & 20 \\
\hline \multirow[t]{10}{*}{ Leu $2+, 9.3+$} & None & $91,333 \pm 11,166$ & \\
\hline & Histamine $10^{-4} \dot{M}$ & $86,333 \pm 1,333$ & 5 \\
\hline & Histamine $10^{-4} \mathrm{M}$ & & \\
\hline & $\begin{array}{c}+ \text { mepyramine } \\
\text { Histamine } 10^{-4} \mathrm{M}\end{array}$ & $86,666 \pm 8,833$ & 5 \\
\hline & + cimetidine & $100,000 \pm 3,333$ & -9 \\
\hline & Histamine $10^{-3} \mathrm{M}$ & $80,666 \pm 5,500$ & 12 \\
\hline & Histamine $10^{-3} \mathrm{M}$ & & \\
\hline & + mepyramine & $95,333 \pm 6,166$ & -4 \\
\hline & Histamine $10^{-3} \mathrm{M}$ & & \\
\hline & + cimetidine & $101,333 \pm 7,000$ & -11 \\
\hline
\end{tabular}

* Each culture contained PWM, $1 \times 10^{5}$ non-T cells, $2 \times 10^{5}$ Leu $3+$ cells, and $2 \times 10^{5}$ regulator Leu $2+$ cells. Mepyramine and cimetidine were used at $10^{-6}$ and $2 \times 10^{-5} \mathrm{M}$, respectively. $\ddagger \mathrm{PFC} \pm 1 \mathrm{SD}$ per $10^{6}$ non-T responder cells initially cultured. histamine. After incubation in $10^{-3} \mathrm{M}$ or $10^{-4} \mathrm{M}$ histamine for $12 \mathrm{~h}$, Leu 2+, 9.3- cells maximally suppressed the in vitro proliferative response of Leu 3+ (helper/inducer) cells to PHA. The same subset of Leu 2+ cells also suppressed PWMinduced B cell differentiation. Previously, we reported that the Leu $2+, 9.3+$ subpopulation includes all or nearly all class I (HLA A, B) major histocompatibility complex alloantigenspecific cytolytic cells, whereas the Leu $2+, 9.3-$ subpopulation includes all precursors of class II (HLA DR) major histocompatibility complex alloantigen-specific suppressor T cells (19). In addition, we have recently shown that suppressor $\mathrm{T}$ cells specific for a soluble antigen, purified protein derivative of tuberculin also derived from the Leu $2+, 9.3-$ subpopulation (21). This subset thus contains virtually all histamine-induced suppressor cells, as well as the majority of suppressor cells activated in several additional in vitro systems.

Other investigators have shown that histamine-induced suppressor $\mathrm{T}$ cells can inhibit the immune response to stimuli in addition to those studied here, and although suppression in these systems has not yet been shown to be mediated by the Leu 2+, 9.3- subset, it seems likely that this is the case. If a single $T$ cell type is inducible with histamine to become suppressive of the immune response, then it is possible that a single mechanism is responsible for suppression, regardless of the stimulus. In this regard, all of the responses known to be affected by histamine-induced suppressor cells are dependent on the activation of $\mathrm{T}$ helper/inducer cells which are, in turn, dependent on their interaction with accessory non-T cells. Presumably, one of these latter cell types is the primary target of suppression. Our data are compatible with either possibility.

In some experiments the addition of Leu $2+, 9.3+$ cells to Leu $3+$ cells resulted in modest inhibition of proliferation. This inhibitory effect was variable, but always less than that of Leu 2+, 9.3- cells, and was neither augmented by histamine nor blocked by histamine antagonists. We interpret these data as indicating that the modest inhibitory effect of Leu $2+, 9.3+$ cells is mediated by a mechanism distinct from that of Leu $2+, 9.3-$ cells.

The precise mechanism whereby histamine-activated Leu $2+, 9.3-$ cells suppress the immune response was not addressed in this study. However, detailed analysis of the inhibition of the proliferative response to PHA ruled out altered kinetics of 
the response as an explanation for suppression, and analogous studies of the inhibition of PWM-induced B cell differentiation by histamine-activated suppressor cells gave similar results (data not shown). Furthermore, histamine-induced suppressive activity was not abolished by irradiation of Leu 2+, 9.3- cells with 1,200 rad either before or after their exposure to histamine, suggesting that these cells need not proliferate to become suppressor cells or to exert suppression. This observation is compatible with the results of other studies indicating that histamine-induced suppressor cells mediate their effects via release of soluble factors $(10,27)$. It would be of interest to examine the effect of supernatants of Leu $2+, 9.3-$ cells after their exposure to histamine.

The apparent difference between our results and those of a previous study (1) showing that suppressive activity induced by histamine was abolished by 1,200 rad may be explained by our use of purified $T$ cell subpopulations and longer (12 vs. 3 h) incubations with histamine. Indeed, in our hands, after exposure to histamine, a minimum of $6 \mathrm{~h}$ incubation was required for Leu $2+, 9.3-$ cells to fully mature into suppressoreffector cells. However, despite this 6-h incubation requirement, as little as $30 \mathrm{~s}$ exposure to histamine was sufficient to trigger this differentiation process (Fig. $4 \mathrm{~B}$ ).

Our results do not necessarily indicate that histamine exerted an immediate effect on Leu $2+, 9.3-$ cells, as the possibility exists that histamine remained on the cell surface following the removal of histamine-containing medium. However, we have shown recently that exposure of Leu 2+, 9.3cells but not Leu $2+, 9.3+$ cells to histamine for $30 \mathrm{~s}$ results in an immediate fivefold rise in intracellular adenosine $3^{\prime}, 5^{\prime}$ monophosphate (cyclic AMP). (Khan, M., P. Sansoni, E. Engleman, and K. Melmon, manuscript submitted for publication.) Furthermore, both the induction of suppressor cells and the rise in intracellular cyclic AMP induced by histamine are blocked by histamine type 2 receptor antagonists but not by $H_{1}$ receptor antagonists. Although these two effects of histamine have not yet been shown to be directly related to one another, it is interesting to speculate that binding of histamine to $\mathrm{H}_{2}$ receptors on the surface of Leu 2+, 9.3- cells leads rapidly to the activation of intracellular adenylate cyclase, which results in the accumulation of intracellular cyclic AMP. The rise in cyclic AMP, in turn, is postulated to initiate the subsequent steps necessary for the activation of histamineinduced suppressor cells.

We have demonstrated that histamine activates a distinct subset of Leu $2+$ cells to become suppressor-effector cells in vitro. Others have suggested that the release of histamine from basophils and eosinophils can directly activate suppressor cells to modify the immune response in vivo (10). Abnormal numbers of lymphocytes that have histamine receptors are present in patients with autoimmune diseases, histiocytosis-x, allergy, and lymphoma (28-30). Furthermore, antigen-specific suppressor cells bearing histamine receptors are generated during desensitization of patients with ragweed allergy (31). In case reports, the administration of the $\mathrm{H}_{2}$ receptor antagonist, cimetidine, was associated with acute, irreversible renal allograft rejection (32). In addition, a controlled trial of cimetidine restored defective cell-mediated immunity in patients with chronic mucocutaneous candidiasis (33). It may therefore be significant that physiologic concentrations of histamine specifically induced Leu $2+, 9.3-$ cells to become suppressor cells. It is possible that Leu $2+, 9.3-$ histamine-inducible suppressor cells are important for normal immunoregulation and that abnormal numbers or function of these cells are responsible for the previously mentioned pathologic conditions.

\section{Acknowledgments}

This work was supported by National Institutes of Health grants CA 24607, HL13108, HL26340, and a grant from the Veterans Administration.

\section{References}

1. Thomas, Y., R. Huchet, and D. Granjon. 1981. Histamineinduced suppressor cells of lymphocyte mitogenic response. Cell. Immunol. 59:268-275.

2. Badger, A. M., J. Young, and G. Poste. 1983. Inhibition of phytohaemagglutinin-induced proliferation of human peripheral blood lymphocytes by histamine and histamine $\mathrm{H}_{1}$ and $\mathrm{H}_{2}$ agonists. Clin. Exp. Immunol. 51:178-184.

3. Melmon, K. L., H. R. Bourne, Y. Weinstein, G. M. Shearer, J. Kram, and S. Bauminger. 1974. Hemolytic plaque formation by leukocytes in vitro. J. Clin. Invest. 53:13-21.

4. Plaut, M., L. M. Lichtenstein, E. Gillespie, and C. S. Henney. 1973. Studies on the mechanism of lymphocyte-mediated cytolysis. IV. Specificity of the histamine receptor on effector T cells. J. Immunol. 111:389-394.

5. Plaut, M., L. M. Lichtenstein, and C. S. Henney. 1973. Increase in histamine receptors on thymus-derived effector lymphocytes during the primary immune response to alloantigens. Nature (Lond.). 244:284287.

6. Plaut, M., L. M. Lichtenstein, and C. S. Henney. 1975. Properties of a subpopulation of $\mathrm{T}$ cells bearing histamine receptors. J. Clin. Invest. 55:856-874.

7. Schwartz, A., P. W. Askenase, and R. K. Gershon. 1980. Histamine inhibition of the in vitro induction of cytotoxic T-cell responses. Immunopharmacology. 2:179-190.

8. Bourne, H. R., L. M. Lichtenstein, K. L. Melmon, C. S. Henney, Y. Weinstein, and G. M. Shearer. 1976. Modulation of inflammation and immunity by cyclic AMP. Science (Wash. DC). 184:19-28.

9. Rocklin, R. E. 1976. Modulation of cellular-immune responses in vivo and in vitro by histamine receptor-bearing lymphocytes. $J$. Clin. Invest. 57:1051-1058.

10. Rocklin, R. E., J. Bread, S. Gupta, R. A. Good, and K. L. Melmon. 1980. Characterization of the human blood lymphocytes that produce a histamine-induced suppressor factor (HSF). Cell. Immunol. 51:226-237.

11. Lima, M., and R. E. Rocklin. 1981. Histamine modulates in vitro IgG production by pokeweed mitogen-stimulated human mononuclear cells. Cell. Immunol. 64:324-336.

12. Damle, N. K., and S. Gupta. 1981. Autologous mixed lymphocyte reaction in man. II. Histamine-induced suppression of the autologous mixed lymphocyte reaction by $\mathrm{T}$ cell subset defined with monoclonal antibodies. J. Clin. Immunol. 1:241-249.

13. Reinherz, E. L., P. C. Kung, G. Goldstein, and S. F. Schlossman. 1980. A monoclonal antibody reactive with the human cytotoxic/ suppressor $\mathrm{T}$ cell subset previously defined by a heteroantiserum termed TH2. J. Immunol. 124:1301-1307.

14. Reinherz, E. L., and S. F. Schlossman. 1980. The differentiation and function of human T lymphocytes. Cell. 19:821-827.

15. Evans, R. L., D. W. Wall, C. D. Platsoucas, F. P. Siegal, S. M. Fikrig, C. M. Testa, and R. A. Good. 1981. Thymus-dependent membrane antigens in man: inhibition of cell-mediated lympholysis by monoclonal antibodies to TH2 antigen. Proc. Natl. Acad. Sci. USA. 78:544-548.

16. Kotzin, B. L., C. J. Benike, and E. G. Engleman. 1981. Induction of immunoglobulin-secreting cells in the allogeneic mixed 
leukocyte reaction: regulation by helper and suppressor lymphocyte subsets in man. J. Immunol. 127:931-935.

17. Gatenby, P. A., B. L. Kotzin, and E. G. Engleman. 1981. Induction of immunoglobulin-secreting cells in the human autologous mixed leukocyte reaction: regulation by helper and suppressor lymphocyte subsets defined with monoclonal antibodies. J. Immunol. 127:2130-2135.

18. Reinherz, E. L., P. C. Kung, G. Goldstein, and S. F. Schlossman. 1979. Separation of functional subsets of human $T$ cells by a monoclonal antibody. Proc. Natl. Acad. Sci. USA. 76:4061-4065.

19. Damle, N. K., N. Mohagheghpour, J. A. Hansen, and E. G. Engleman. 1983. Alloantigen-specific cytotoxic and suppressor T lymphocytes are derived from phenotypically distinct precursors. J. Immunol. 131:2296-2300.

20. Damle, N. K., and E. G. Engleman. 1983. Immunoregulatory $T$ cell circuits in man. Alloantigen primed inducer $T$ cells activate alloantigen-specific suppressor $\mathrm{T}$ cells in the absence of the initial antigenic stimulus. J. Exp. Med. 158:159-173.

21. Damle, N. K., N. Mohagheghpour, and E. G. Engleman. 1984. Soluble antigen-primed inducer $\mathrm{T}$ cells activate antigen-specific suppressor $\mathrm{T}$ cells in the absence of antigen-pulsed accessory cells. Phenotypic definition of suppressor-inducer and suppressor-effector cells. J. Immunol. 132:644-650.

22. Hansen, J. A., P. J. Martin, and R. C. Nowinski. 1980. Monoclonal antibody identifying a novel T-cell antigen and Ia antigens of human lymphocytes. Immunogenetics. 10:247-260.

23. Boyum, A. 1968. Isolation of mononuclear cells and granulocytes from human blood. Scand. J. Clin. Lab. Invest. 21(Suppl. 97):77.

24. Saxon, A., J. Feldhous, and R. A. Robins. 1976. Single step separation of human $\mathrm{T}$ and $\mathrm{B}$ cells using AET-treated sheep red cells. J. Immunol. Methods. 12:285-288.
25. Gronowicz, E., A. Coutinho, and F. Melchers. 1976. A plaque assay for all cells secreting Ig of a given type or class. Eur. J. Immunol. 6:588-590.

26. Bristow, M. R., R. Cubicciolti, R. Ginsburg, E. B. Stinson, and C. Johnson. 1982. Histamine-mediated adenylate cyclase stimulation in human myocardium. Mol. Pharmacol. 21:671-679.

27. Garovoy, M. R., M. A. Reddish, and R. E. Rocklin. 1983. Histamine-induced suppressor factor (HSF): inhibition of helper T cell generation and function. J. Immunol. 130:357-360.

28. De Cock, W., J. De Cree, and H. Verhaegen. 1978. Histamine receptor-bearing $\mathrm{T}$ lymphocytes in patients with allergy, autoimmune disease, or recurrent infection. Clin. Immunol. Immunopathol. 11:1-5.

29. Osband, M. E., J. M. Lipton, P. Lavin, R. Levey, G. Vawter, J. S. Greenberger, R. P. McCaffrey, and R. Parkman. 1981. Histiocytosis$\mathrm{x}$ : demonstration of abnormal immunity, T-cell histamine H2-receptor deficiency, and successful treatment with thymic extract. N. Engl. J. Med. 304:146-153.

30. Zarling, J. M., C. Berman, and P. C. Raich. 1980. Depressed cytotoxic T-cell responses in previously treated Hodgkin's and nonHodgkin's lymphoma patients. Cancer Immunol. Immunother. 7:243249.

31. Rocklin, R. E., A. L. Sheffer, D. K. Greineder, and K. L. Melmon. 1980. Generation of antigen-specific suppressor cells during allergy desensitization. N. Engl. J. Med. 302:1213-1219.

32. Primack, W. A. 1978. Cimetidine and renal-allograft rejection. Lancet. I:824-825.

33. Jorizzo, J. L., W. M. Sams, B. U. Jegasothy, and A. J. Olansky. 1980. Cimetidine as an immunomodulator: chronic mucocutaneous candidiasis as a model. Ann. Intern. Med. 92:192-195. 